\title{
Influence of compost and liquid bioferment on the chemical and biological characteristics of soil cultivated with banana (Musa spp. L.)
}

\author{
M. de L. Adriano ${ }^{1}$, F. Gutiérrez ${ }^{2}$, L. Dendooven ${ }^{3}$ and M. Salvador-Figueroa ${ }^{1}$ * \\ ${ }^{1}$ Centro de Biociencias. Universidad Autónoma de Chiapas. Carretera a Puerto Madero Km 2.0 Tapachula, \\ 30700, Chiapas. ${ }^{2}$ Instituto Tecnológico de Tuxtla Gutiérrez. ${ }^{3}$ Laboratory of Soil Ecology, GIB, Cinvestav, \\ México. "Corresponding author: msalvad@hotmail.com
}

\begin{abstract}
The effects of compost and liquid biofertiliser on the chemical and biological characteristics of soil cultivated with banana (Musa spp. L.) cv. 'Grand Naine' were investigated. Four treatments (liquid bioferment (LBF), compost (COM), liquid bioferment + compost (LBF + COM) and unamended (CONTROL)) were applied to banana plants in the field in a completely randomised design in the crop cycles of 2005-2006 and 2007-2008. The physico-chemical characteristics, enzymatic activity and microbial diversity were determined prior to the bioferment addition and 140 and 280 days after application (DAP). The microbial groups were determined (i.e., bacteria, fungi, actinomycetes). Next, cellulolytic, proteolytic, starch hydrolysing, asymbiotic $\mathrm{N}_{2}$-fixing and phosphorous-solubilising microorganisms were determined. The application of $\mathrm{LBF}+\mathrm{COM}$ increased organic matter 1.39 times, increased compost 1.33 times and increased LBF 1.16 times at 140 DAP. The greatest microbial populations were found in soil amended with LBF + COM at 140 DAP. The highest esterase and invertase enzyme activities were found in soil amended with LBF $+\mathrm{COM}$ at 140 DAP. The highest xylanase activity was found in soil amended with compost at 280 DAP. These results showed that the addition of compost and liquid bioferment improves soil fertility and stimulates microbial activity and their capacity to metabolise complex organic molecules.

Keywords: enzyme activities, cellulolytic microorganisms, proteolytic microorganisms, starch hydrolysing microorganisms, asymbiotic $\mathrm{N}_{2}$ fixing microorganisms, phosphorous solubilising microorganisms.
\end{abstract}




\section{Introduction}

Restoring and sustaining the soil fertility of banana fields (Musa spp. L.) has become an important topic in recent years (Bouman et al., 1998). The international network for the improvement of banana and platano (INIBAP), the network research and development of banana and plantain of Latin America and the Caribbean (MUSALAC) and the regional fund for agricultural technology (FONTAGRO) have developed the project "Technological innovations in the management of health and quality of banana soils in Latin America and the Caribbean". The aim of this joint project was to restore the productivity of banana plantations by improving the physical, chemical and biological characteristics of soil. Various strategies were suggested and tested to achieve this objective. It was suggested that the addition of organic matter $(\mathrm{OM})$ in different forms might restore soil fertility and promote sustainable agricultural practices. It is well known that applying OM to soil improves soil structure, aeration and water retention. Organic matter also serves as a C-substrate for soil macrofauna and microorganisms. After its mineralisation, $\mathrm{OM}$ provides nutrients for crops and might produce a number of organic substances that increase soil fertility and plant development. Despite the well-known fact that OM application improves soil fertility, this practise is not often used in the cultivation of bananas.

Organic matter decomposition is catalysed by enzymes, which play an important role in biogeochemical cycles (Wittmann et al., 2004). Enzyme activity in soil is used as an indicator of changes in the quality and fertility of soil (Qu et al., 2011) and is studied when a factor, such as organic material application, might affect soil microbial activity and nutrient cycling (Alotaibi and Schoenau, 2011). The objective of this work was to study the effect of adding two different forms of organic material, i.e., compost and liquid bioferment, on the chemical and biological characteristics of soil cultivated with the banana cv. "Grand Naine".

\section{Materials and Methods}

\subsection{Location of the study site}

The study was conducted in a banana plantation located in Tapachula, Chiapas, Mexico (92 $22^{\circ}$ '26.96" $\mathrm{W} ; 14^{\circ} 50^{\prime} 36.82^{\prime}$ N; 34 masl). The field had been cultivated with bananas (Musa AAA Cavendish cv "Grand Naine") in a conventional way (using fertilisers and chemical pesticides) for more than 20 years.

\subsection{Compost production}

Leaves, pseudostems, rachis and fruits of banana plants were stacked in approximately $1000-\mathrm{kg}$ piles and covered with black plastic to reduce water loss and avoid the invasion of flies and rodents. The compost was aerated by being manually turned over every 7 days until stabilisation (12 weeks). The characteristics of the compost with a water content of $600 \mathrm{~g} \mathrm{~kg}^{-1}$ were on a dry weight basis as follows: organic carbon: $222 \mathrm{~g} \mathrm{~kg}^{-1}$, total nitrogen: $20 \mathrm{~g} \mathrm{~kg}^{-1}$, phosphorus as $\mathrm{P}_{2} \mathrm{O}_{5}: 11 \mathrm{~g} \mathrm{~kg}^{-1}$ and potassium as $\mathrm{K}_{2} \mathrm{O}: 13.38 \mathrm{~g} \mathrm{~kg}^{-1}$.

\subsection{Liquid bioferment production}

Liquid bioferment was prepared by mixing $50 \mathrm{~kg}$ fresh cattle manure, $20 \mathrm{~kg}$ sugarcane molasses, $4 \mathrm{~kg}$ ash, 21 microbial inoculant to accelerate the fermentation (see below) and tap water until reaching a final volume of 2001 . The mixture was anaerobically fermented in a hermetically sealed tank for 21 days. At the end of fermentation, 11 of the promoting growth plant microorganisms (see below) and 11 of phos- 
phate-solubilising fungi (see below) were added and the mixture was left for $48 \mathrm{~h}$. The liquid bioferment average composition ( $\mathrm{w} \mathrm{V}^{-1}$ ) was as follows: total nitrogen: $1.5 \%, \mathrm{P}_{2} \mathrm{O}_{5}: 0.98 \%$ and $\mathrm{K}_{2} \mathrm{O}: 1.04 \%$.

\subsection{Production of fermentation microorganisms}

A vial of yeast isolated from 'pozol', a traditional beverage from Chiapas (México), was resuspended in a 1:1 sterile Sabouraud broth culture medium at $\mathrm{pH}$ 6.5. The vessel was maintained at $28{ }^{\circ} \mathrm{C}$ with agitation at $200 \mathrm{rpm}$ for $24 \mathrm{~h}$ (for a final cell concentration of $10^{9}$ $\mathrm{ml}^{-1}$ ). Further details of the isolation method can be found in Alcántara-Hernández et al. (2010).

\subsection{Production of plant growth promoting microorganisms}

A vial of a free-living $\mathrm{N}_{2}$ fixing bacteria isolated from the banana soil was resuspended in a 1-1 sterile culture medium (nutrient broth) at $\mathrm{pH}$ 7.0. The vessel was maintained at $28{ }^{\circ} \mathrm{C}$ with agitation at $200 \mathrm{rpm}$ for 12 h. The final cell concentration was $10^{11}$ colony former units (CFU) $\mathrm{ml}^{-1}$.

\subsection{Treatments}

In 2005, four treatments were applied to newly planted banana plants $\left(1,000 \mathrm{~m}^{2}\right.$ with 180 plants per plot $\left.{ }^{-1}\right)$ in triplicate using a randomised block design. In treatment $1,20 \mathrm{~kg}$ dry compost was applied once to the base of each banana plant (considered the COM treatment). In treatment 2, $10 \mathrm{~kg}$ dry compost was applied once, while 2:1 liquid bioferment (dilution 1:2) was sprayed six times on the leaves and soil surrounding each banana pseudostem every three days (considered the $\mathrm{LBF}+\mathrm{COM}$ treatment). In treatment 3,41 of liquid bioferment (dilution 1:2) was sprayed six times on the leaves and soil every three days (considered the LBF treatment). In treatment 4, $340 \mathrm{~g}$ urea was applied around each banana plant (considered the CONTROL treatment). Compost and liquid bioferment were applied at a rate of $160 \mathrm{~g} \mathrm{~N}$ plant ${ }^{-1}$. The same treatments were applied in the 2007 crop cycle.

\subsection{Soil samples}

In the crop cycles 2005-2006 and 2007-2008, soil samples were taken from the 0-30-cm depth layer just after the bananas were planted (August) but before the treatments were applied and 140 (January) and 280 (June) days after application of the treatments. In the first sampling, 10 soil samples were taken systematically (zigzag) from the $0-30$-cm depth layer in each plot. In the second and third samplings, 10 soil samples were taken from the area around 10 randomly selected plants in each of the three plots of each of the four treatments. In both cases, one kilogramme of soil was collected. The banana plants were also sampled at the second and third samplings. The banana roots were separated from the soil and used to quantify the associated microorganisms. The soil was sieved at $<2$ $\mathrm{mm}$. Part of the soil was characterised as described in Ruíz-Valdiviezo et al. (2010), while another portion was stored at $-30^{\circ} \mathrm{C}$ until it was used for the enzymatic analysis.

\subsection{Phosphate-solubilising fungi}

Phosphate-solubilising fungi isolated from banana soil was grown in Roux bottles using potato dextrose agar (PDA). After inoculation with $1 \mathrm{ml}$ spore suspension $\left(10^{6}\right.$ spores $\left.\mathrm{ml}^{-1}\right)$, bottles were incubated at $32{ }^{\circ} \mathrm{C}$ until sporulation (7 days). The spores were collected in a Ringer's solution and diluted to 11 in sterilised water (the final spore concentration was $10^{8}$ spores $\mathrm{ml}^{-1}$ ). 


\subsection{Quantification of microorganisms associated with the banana roots}

Ten grammes of roots were suspended in $100 \mathrm{ml}$ sterile water and stirred under aseptic conditions at 100 rpm for $30 \mathrm{~min}$. Serial dilutions up to $10^{5}$ were made of the supernatant and $100 \mu \mathrm{l}$ aliquots of the last dilution were inoculated in different culture media. Aerobic mesophilic bacteria were quantified (colony forming units, $\mathrm{CFU})$ in a nutrient medium $(\mathrm{pH} 7.0)$. The nutrient medium was incubated at $37^{\circ} \mathrm{C}$ for $48 \mathrm{~h}$. The fungi were quantified in potato-dextrose agar (pH 5.6) after incubation at $37{ }^{\circ} \mathrm{C}$ for 5 days. Actinomycetes were quantified in a Czapeck-Dox-Agar medium $(\mathrm{pH}$ 7.3) after incubation at $37^{\circ} \mathrm{C}$ for 5 days.

\subsection{Substrate utilisation profile and soil enzymatic activity}

Microbial cellulolytic, amylolytic, asymbiotic nitrogen fixation and phosphate solubilising capacities were determined as described by Hankin and Anagnostakis (1977), Castro et al. (1993), McKinley (2001) and Alam et al. (2002), respectively. The proteolytic capacity was enumerated using a gelatin agar (consisting of nutrient agar [Difco Laboratories, Detroit, MI] and 3\% [ $\mathrm{w} \mathrm{v}^{-1}$ ] gelatin [Sigma, St. Louis, $\mathrm{MO}]$ ) as the differential medium.

Invertase activity was determined by the Hofmann method (Kokalis-Burelle et al., 1994), esterase activity was determined by hydrolysis of fluorescein diacetate (FDA), as described by Kokalis-Burelle et al. (1994) and the xylanase activity was measured us- ing the procedure described by Bailey et al. (1992), using birch glucoronoxilan as a substrate.

\subsection{Statistical analysis}

Organic matter; $\mathrm{N}, \mathrm{P}, \mathrm{K}, \mathrm{Ca}$ and $\mathrm{Mg}$ content; $\mathrm{pH}$; electrolytic conductivity (EC); the number of different microorganism groups; and esterase, invertase and xylanase activities were subjected to one-way analysis of variance using PROC GLM (SAS Institute Inc., 1989) to test for significant differences between treatments with the Tukey's Studentised Range test. All data presented were the mean of three different plots, i.e., $n=3$.

\section{Results}

\subsection{Physico-chemical characteristics of the soil} Application of compost or compost+fertiliser increased SOM compared with the control soil and soil amended with fertiliser after 0,140 and 280 days (Fig. 1a). The electrolytic conductivity and the total $\mathrm{P}, \mathrm{K}, \mathrm{Ca}$ and $\mathrm{Mg}$ content increased when compost or compost+fertiliser was added to soil compared with the control soil and soil amended with fertiliser after 140 and 280 days (Figures 1b, c, d, e, f, g, h). The effect, however, was more prominent after 140 days than after 280 days. The measured soil characteristics were significantly affected by treatment (control, compost, fertiliser and compost+fertiliser), time ( 0 , 140 and 280 days) and the interaction between them, except for the interaction between treatment and time on soil total $\mathrm{N}(p<0.05)$ (Table 1$)$. 
Fig. 1
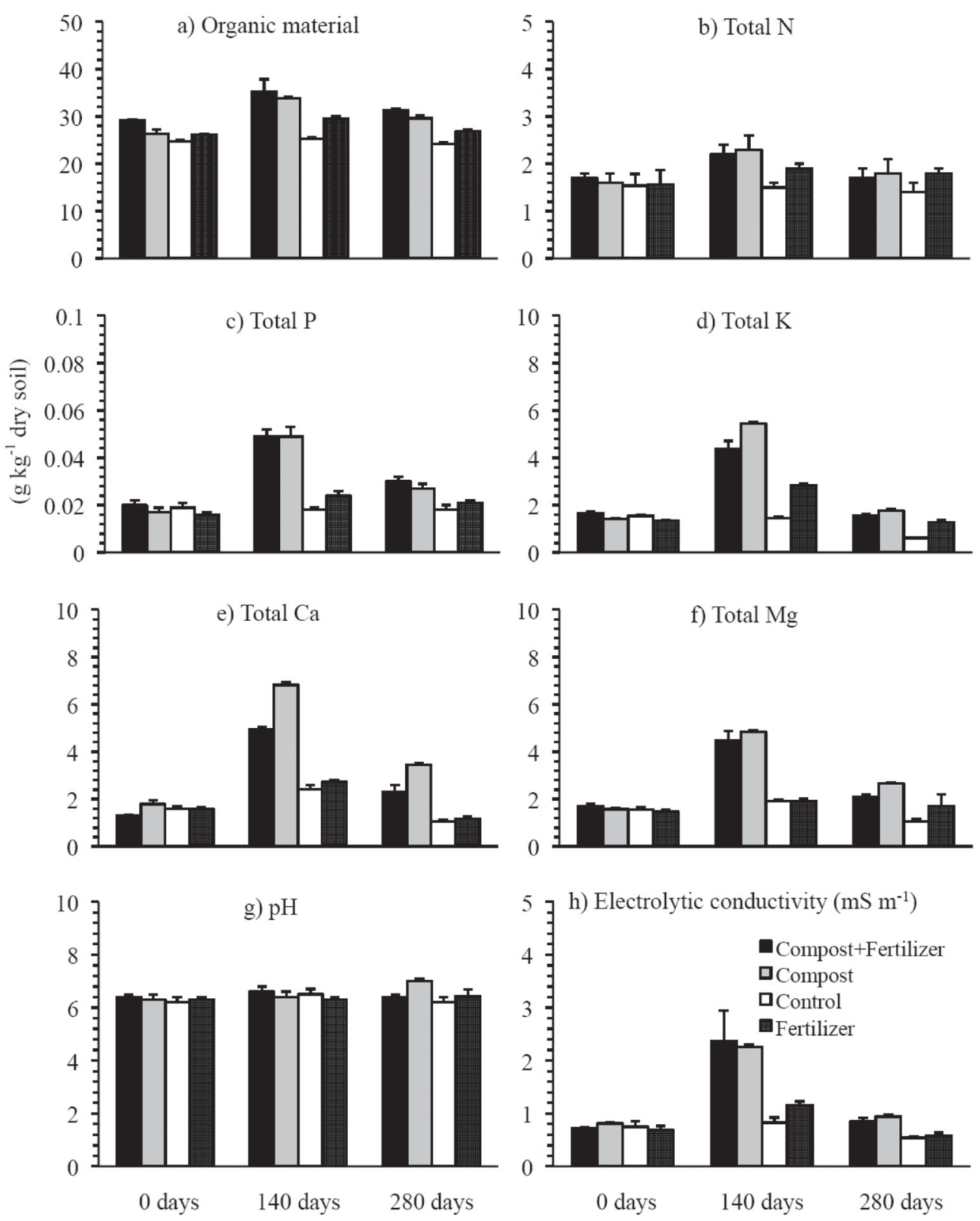

Figure 1. a) Organic matter content, b) total $\mathrm{N}$, c) total $\mathrm{P}$, d) total $\mathrm{K}$, e) total $\mathrm{Ca}$, f) total $\mathrm{Mg}$ ( $\mathrm{g} \mathrm{kg}^{-1}$ dry soil), g) $\mathrm{pH}$ and h) electrolytic conductivity ( $\left.\mathrm{mS} \mathrm{m}^{-1}\right)$ in soil cultivated with banana (Musa spp. L.) amended with compost, fertilizer or compost + fertilizer, or left unamended after 0, 140 and 280 days. 
Table 1. Characteristics of unamended and amended soils cultivated with the banana clone "Grand Naine".

\begin{tabular}{lcccccc}
\hline & \multicolumn{2}{c}{ Treatment } & \multicolumn{2}{c}{ Time } & \multicolumn{2}{c}{ Treatment'Time } \\
\hline Soil characteristics & F value & P value & F value & P value & F value & P value \\
\hline Organic mater & 123.90 & $<0.0001$ & 85.32 & $<0.0001$ & 10.67 & $<0.0001$ \\
Total N & 7.40 & 0.0011 & 10.57 & 0.0005 & 2.01 & 0.1037 \\
Total P & 105.71 & $<0.0001$ & 191.14 & $<0.0001$ & 43.79 & $<0.0001$ \\
Total K & 368.33 & $<0.0001$ & 1348.88 & $<0.0001$ & 183.12 & $<0.0001$ \\
Total Ca & 594.40 & $<0.0001$ & 1370.94 & $<0.0001$ & 173.60 & $<0.0001$ \\
Total Mg & 127.96 & $<0.0001$ & 251.36 & $<0.0001$ & 48.42 & $<0.0001$ \\
pH & 4.46 & $<0.0001$ & 4.71 & $<0.0001$ & 4.97 & $<0.0001$ \\
Electrolytic conductivity & 31.95 & $<0.0001$ & 109.83 & $<0.0001$ & 15.42 & $<0.0001$
\end{tabular}

Microbial organisms

\begin{tabular}{lcccccc}
\hline Aerobic mesophilic & 47.10 & $<0.0001$ & 17.26 & $<0.0001$ & 12.99 & $<0.0001$ \\
Actinomycetes & 26.54 & $<0.0001$ & 30.37 & $<0.0001$ & 23.93 & $<0.0001$ \\
Fungi & 3.11 & $<0.0001$ & 0.28 & $<0.0001$ & 5.77 & $<0.0001$ \\
Cellulolytic & 4.67 & 0.0074 & 10.00 & 0.0004 & 7.98 & $<0.0001$ \\
Amylolytic & 10.46 & $<0.0001$ & 18.64 & $<0.0001$ & 7.71 & $<0.0001$ \\
Proteolytic & 39.05 & $<0.0001$ & 99.78 & $<0.0001$ & 19.56 & $<0.0001$ \\
Phosphate solubilising & 48.19 & $<0.0001$ & 27.96 & $<0.0001$ & 28.33 & $<0.0001$ \\
$\mathrm{~N}_{2}$ fixing & 291.40 & $<0.0001$ & 996.77 & $<0.0001$ & 106.79 & $<0.0001$
\end{tabular}

Enzyme activity

\begin{tabular}{lrrrrrr} 
& 154.41 & $<0.0001$ & 176.86 & $<0.0001$ & 54.72 & $<0.0001$ \\
Esterase & 58.82 & $<0.0001$ & 145.06 & $<0.0001$ & 22.22 & $<0.0001$ \\
Invertase & 121.27 & $<0.0001$ & 181.07 & $<0.0001$ & 34.29 & $<0.0001$ \\
Xylanase & 121.29 \\
\hline
\end{tabular}

\subsection{Microbial population}

The number of aerobic mesophilic microorganisms increased when compost was added to soil compared with the other treatments at 140 and 280 days (Figure 2a). The number of actinomycetes also increased in the compost-amended soil but only after 140 days
(Figure 2b). The effect of the different treatments on the other microorganisms measured was less clear, although the number of microorganisms increased generally after 140 days and less so after 280 days compared with the number at day 0 (Figures $2 \mathrm{c}, \mathrm{d}, \mathrm{e}, \mathrm{f}, \mathrm{g}$ ). 
The number of free-living $\mathrm{N}_{2}$ fixing bacteria increased in all treatments after 140 and 280 days, but the effect was more prominent after 140 days than after 280 days (Figure $2 \mathrm{~h}$ ). The measured soil microorganisms were significantly affected by treatment, time and the interaction between them $(p<0.01)$ (Table 1).
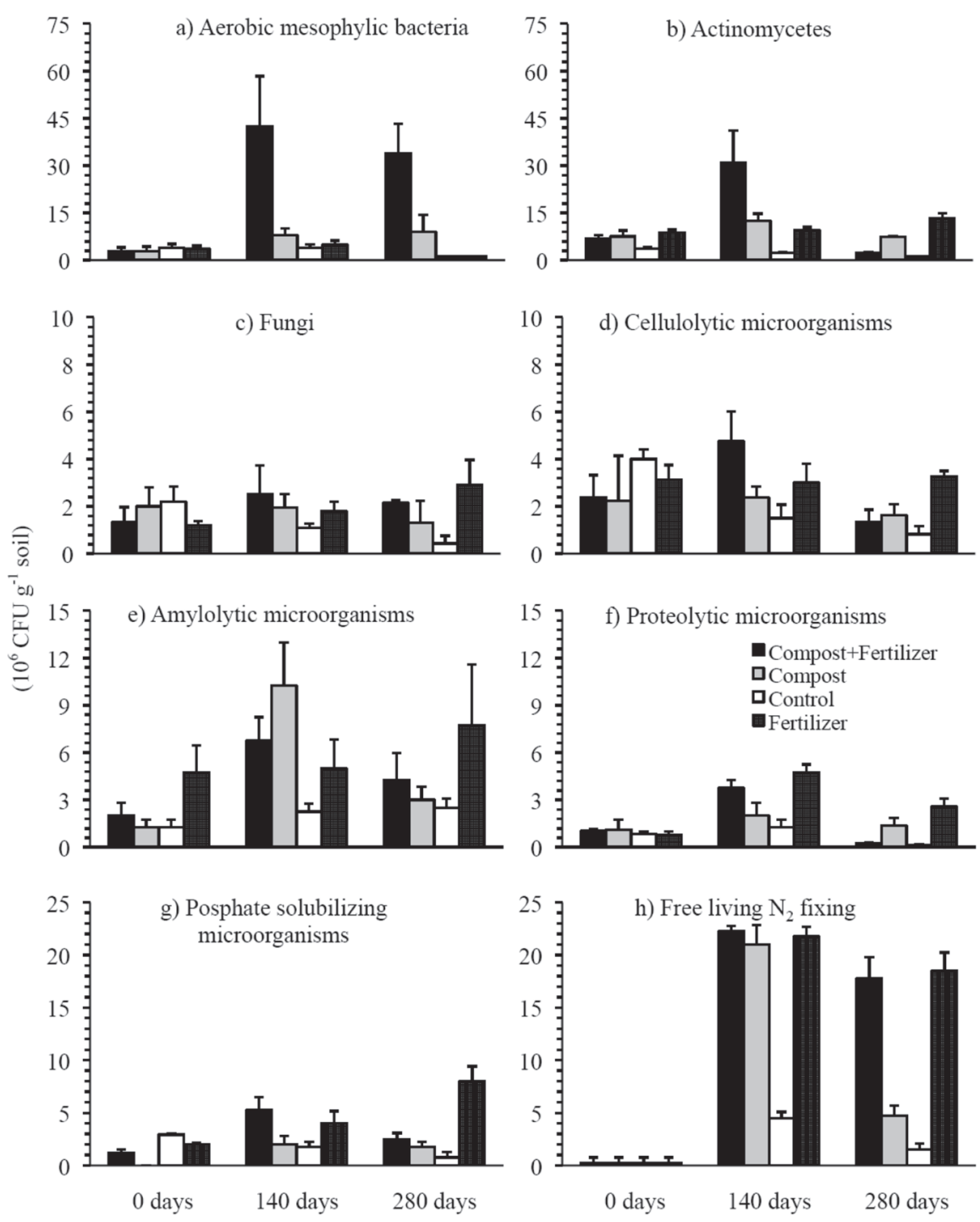

Figure 2. a) Number of aerobic mesophylic bacteria, b) Actinomycetes, c) fungi, d) cellulolytic microorganisms, e) amylolytic microorganisms, f) proteolytic microorganisms, g) phosphate solubilising microorganisms and h) free living $\mathrm{N}_{2}$ microorganisms (106 cell forming units (CFU) $\mathrm{g}^{-1}$ dry soil) in soil cultivated with banana (Musa spp. L.) amended with compost, fertilizer or compost + fertilizer, or left unamended after 0, 140 and 280 days. 


\subsection{Enzyme activities}

The activity of esterase increased when compost and compost + fertiliser were added to the soil compared with the unamended soil and soil amended with fertiliser after 140 and 280 days, with the greatest effect being found in the former
(Figure 3). The activity of invertase also increased when compost and compost + fertiliser were added to soil compared with the unamended soil and soil amended with fertiliser but only after 140 days. The enzyme activity was significantly affected by treatment, time and the interaction between them $(p<0.0001)$ (Table 1).
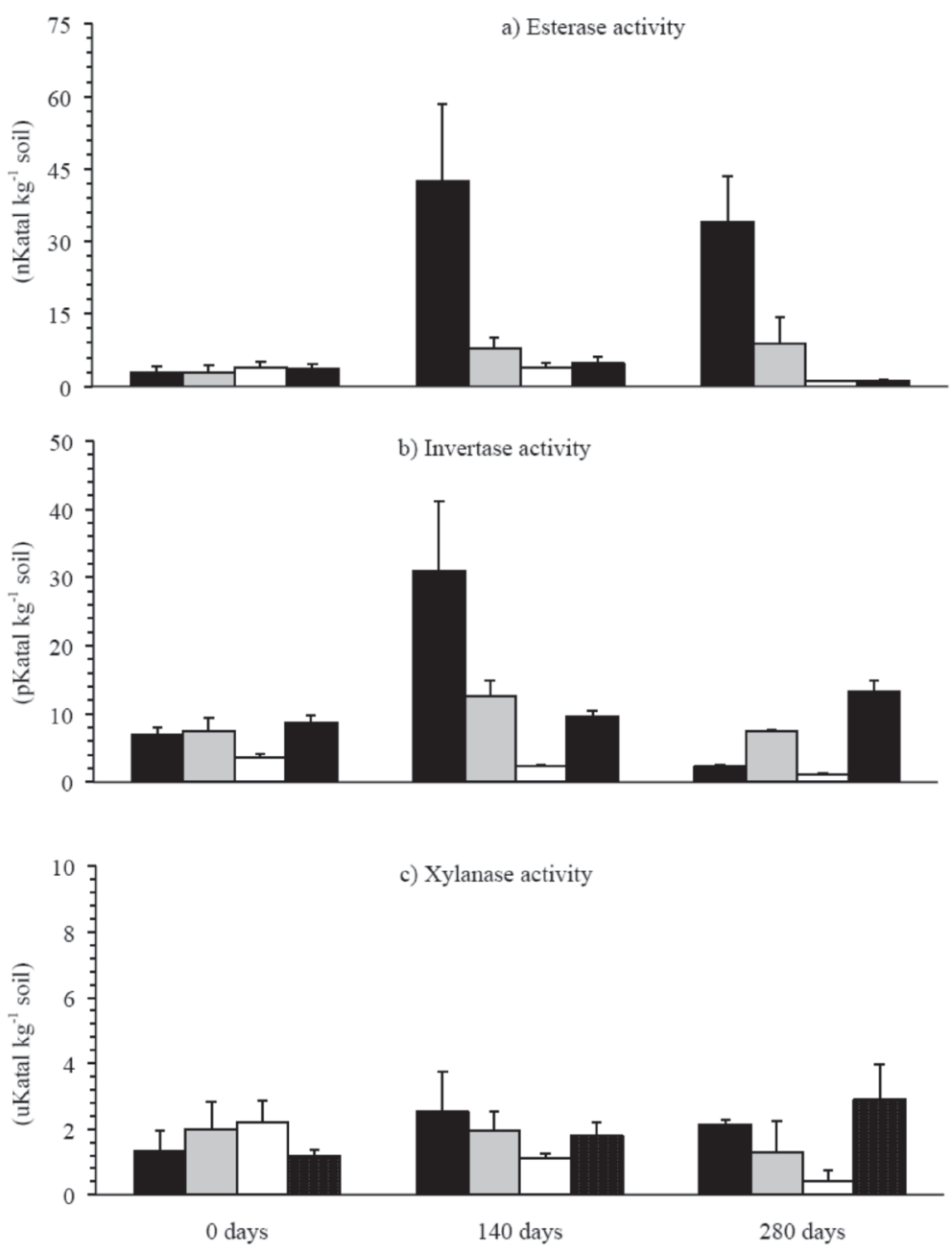

Figure 3. a) Esterase (nKatal kg-1 dry soil), b) invertase (pKatal kg-1 dry soil), and c) xylanase activity ( $\mu \mathrm{Katal} \mathrm{kg}^{-1}$ dry soil) in soil cultivated with banana (Musa spp. L.) amended with compost, fertilizer or compost + fertilizer, or left unamended after 0, 140 and 280 days. Legends to the Figure can be found in Figure 2. 


\section{Discussion}

The increase in $\mathrm{N}, \mathrm{K}, \mathrm{P}, \mathrm{Ca}$ and $\mathrm{Mg}$ content in soils is closely related to the accumulation of OM (Table 1). Similar results have been reported in soils amended with different forms of organic wastes, i.e., compost derived from sewage sludge mixed with cotton gin waste and/or olive mill wastewater, urban organic waste, domestic organic waste, green waste (leaf falls, tree pruning, garden clippings and other bulky cellulose and lignin-rich materials) and cattle manure (Ros et al., 2006). McClintock and Diop (2005) reported that the addition of compost increased soil $\mathrm{C}$ content from $2.8 \mathrm{~kg} \mathrm{ha}^{-1}$ to $5.0 \mathrm{~kg} \mathrm{ha}^{-1}$, as well as the total amount of $\mathrm{K}, \mathrm{Mg}$ and $\mathrm{P}$. That the amended soil had more available nutrients 140 days after application (DAP) than after 250 days indicated that most of added organic material was mineralised after 140 days (Table 1). This result indicates that as time passed, the mineralisation of the added OM slowed down and fewer nutrients were released. Fabrizio et al. (2009) reported similar results. These researchers found that 150 days after the application of compost, the labile carbon pool was virtually exhausted.

The decrease in easily decomposable organic material (labile carbon fraction) over time was confirmed by the microbial population and enzyme activity in soil (Figures 2 and 3). Even with the limitations of the tests used (Larkin, 2003), the addition of OM increased the microbial biomass in the rhizosphere of banana cv. "Grand Naine". The increase in microorganisms when OM was added to the soil has been reported often (Peacock et al., 2001). The composition of the added organic material is also known to affect the structure of the microbial population (Marschner et al., 2003). Additionally, the cultivated plants affect the composition and activity of the soil microbial community in the rhizosphere (Wardle et al., 2004). The opposite view, that such microorganisms as my- corrhizal fungi determine the plant community, has also been proposed (van der Heijden et al., 1998).

The addition of OM might prolong the presence of microbiota in the rhizosphere of the banana cv. "Grand Naine". Marschner et al. (2003) stated that the application of easily degradable material favoured the growth of microorganisms that prefer environments rich in nutrients (copiotrophos) over organisms adapted to conditions of limited nutrient availability (oligotrophos). Additionally, the incorporation of crop residues favours cellulolytic microorganisms compared with those that cannot degrade cellulose (Debosz et al., 1999). The increase in microbial biomass, as indicated by an increase in esterase activity, was due to the addition of OM, as no such increase was found in the unamended control treatment (Kokalis-Burelle et al. 1994). Similar results were reported when untreated OM or compost were applied to soil (Kandeler et al., 1999; Pérez-Piqueres et al., 2006). The application of compost or the stabilised liquid bioferment increased the availability of precursors for cell metabolism. However, the organic material applied consists mostly of complex organic molecules, as the easily degraded substrate was mineralised during composting and fermentation. As such, the increase and duplication of the microbial biomass was low. The addition of compost and liquid bioferment will change both the amount and composition of the soil microbial biomass. Compost and liquid bioferment also contain microorganisms, which might change the composition of the soil microorganisms.

The activities of invertase, which hydrolyses sucrose into glucose and fructose and xylanases, which hydrolyse hemicellulose, both increased. Similar results were reported by Kandeler et al. (1999), who studied the dynamics of invertases and xylanases in soil amended with corn stubble. Kandeler et al. (1999) found that the activity of invertases increased more than that of xylanases. The characteristics of the OM 
applied also affected the increase in enzyme activity, as Kokalis-Burelle et al. (1994) found that invertase activity doubled in soil amended with pine bark compared with soil amended with composted bark.

\section{Conclusions}

It was concluded that the addition of fermented OM (compost or liquid) increased soil microbial activity and stimulated the production of enzymes degrading organic material. The increased activity of invertases, xylanases and esterases will degrade the added organic material more rapidly, thereby releasing nutrients that are available to the cultivated banana plants or other soil habitants.

\section{Acknowledgments}

The research was funded by FOMIX CONACyT-Estado de Chiapas (Grant CHIS-2006-C06-43894).

\section{References}

Alam, S., Khalil, S., Ayub, N., Rashid, M. 2002. In vitro solubilization of inorganic phosphate by phosphate solubilizing microorganisms (PSM) from maize rhizosphere. International. J. Agr. Biol. 4, 454-458.

Alcántara-Hernández, R.J., Rodríguez-Álvarez, J.A., Valenzuela-Encinas, C., Gutiérrez-Miceli, F.A., Castañón-González, H., Marsch, R., AyoraTalavera, T., Dendooven, L. 2010. The bacterial community in 'taberna' a traditional beverage of Southern Mexico. Lett. App. Microbiol. 51, $558-563$.

Alotaibi, K.D., Schoenau, J.J., 2011. Enzymatic activity and microbial biomass in soil amended with biofuel production byproducts. Appl. Soil Ecol. $48,227-235$
Bailey, M.J., Biely, P., Poutanen, K. 1992. Interlaboratory testing of methods for assay of xylanase activity. J. Biotechnol. 23, 257 - 270.

Bouman, B.A.M., Schipper, R.A. Nieuwenhuyse, A. Hengsdijk, H. Jansen, H.G.P. 1998. Quantifying economic and biophysical sustainability tradeoffs in land use exploration at the regional level: a case study for the Northern Atlantic Zone of Costa Rica. Ecol. Model. 114, 95-109.

Castro, G., Ferrero, M., Méndez, B., Sineriz, F. 1993. Screening and selection of bacteria with high amylolytic activity. Acta Biotechnol. 13, 197-201.

Debosz, K., Rasmussen, P.H., Pedersen, A.R. 1999. Temporal variations in microbial biomass $\mathrm{C}$ and cellulolytic enzyme activity in arable soils: effects of organic matter input. Appl. Soil Ecol. 13, 209218.

Fabrizio, A., Tambone, F., Ganevini, P. 2009. Effect of compost application rate on carbon degradation and retention in soils. Waste Manage. 29, $174-179$.

Hankin, L., Anagnostakis, S. 1977. Solid media containing carboxymethylcellulosa to detect $\mathrm{C}_{\mathrm{x}}$ cellulase activity of microorganisms. J. Gen. Microbiol. 98, 109-115.

Kandeler, E., Tscherko, D., Spiegel, H. 1999. Longterm monitoring of microbial biomass, $\mathrm{N}$ mineralization and enzyme activities of a Chernozem under different tillage management. Biol. Fert. Soils $28,343-351$.

Kokalis-Burelle, N., Rodríguez-Kábana, R., Weaver, C.F., King, P.S. 1994. Evaluation of powderd pine bark for control of Meloidogyne arenaria and Heterodera glycines on soybean. Plant Soil 162, $169-175$.

Larkin, R.P. 2003. Characterization of soil microbial communities under different potato cropping systems by microbial population dynamics, substrate utilization, and fatty acid profiles. Soil Biol. Biochem. 35, 1451-1466. 
Marschner, P., Kandeler, E., Marschner, B. 2003. Structure and function of the soil microbial community in a long-term fertilizer experiment. Soil Biol. Biochem. 35, $453-461$.

McClintock, N., Diop, A.M. 2005. Soil fertility management and compost use in Senegal's peanut basin. Intern. J. Agric. Sustain. 3, 79 - 91.

Mckinley, V. 2001. Microbial biomass and activity in soils from virgin prairies compared with prairies restoration, forest and agricultural sites in Illinois. Proc. $17^{\text {th }}$ Prairie Conference. 107-117.

Peacock, A.D., Mullen, M.D., Ringelberg, D.R., Tyler, D.D., Hedrick, D.B., Gale, P.M., White D.C. 2001. Soil microbial community responses to dairy manure or ammonium nitrate applications. Soil Biol. Biochem. 33, 1011 - 1019.

Pérez-Piqueres, A., Edel-Hermann, V., Alabouvette, C., Steinberg, C. 2006. Response of soil microbial communities to compost amendments. Soil Biol. Biochem. 38, 460 - 470.

Qu, J.J., Ren, G.M., Chen, B., Fan, J.H., E., Y. 2011. Effects of lead and zinc mining contamination on bacterial community diversity and enzyme activities of vicinal cropland. Environ. Monitor. Assess. $182,597-606$.

Ros, M., Klammer, S., Knapp, B., Aichberger, K., Insam, H. 2006. Long-term effects of compost amendment of soil on functional and structural diversity and microbial activity. Soil Use Manage. 22, 209-218

Ruíz-Valdiviezo, V.M., Luna-Guido, M., Galzy, A., Gutiérrez-Miceli, F.A., Dendooven, L. 2010. Greenhouse gas emissions and $\mathrm{C}$ and $\mathrm{N}$ mineralization in soils of Chiapas (México) amended with leaves of piñón (Jatropha curcas L.). Appl. Soil Ecol. 46, 17-25.

SAS Institute 1989. Statistic Guide for Personal Computers. Version 6.04. SAS Institute, Cary. 1989.

van der Heijden, M.G.A., Klinoromos, J.N., Ursic, M., Moutoglis, P., Streitwolf-Engel, R., Boller, T., Wiemkem, A., Sanders, I.R. 1998. Mycorrhizal fungal diversity determines plant biodiversity, ecosystem variability and productivity. Nature $296,69-72$.

Wardle, D.A., Bardgett, R.D., Klironomos, J.N., Setala, H., van der Putten, W.H., Wall D.H. 2004. Ecological linkages between above ground and below ground biota. Science 304, 1629 - 1633.

Wittmann, C., Kähkönen, M.A., Ilevesniemi, H., Kurola, J., Salkinoja-Salonen, M.S., 2004. Areal activities and stratification of hydrolytic enzymes involved in the biochemical cycles of carbon, nitrogen, sulphur and phosphorus in podsolized boreal forest soils. Soil Biol. Biochem. 36, 425 -433 . 
